DOI: http://dx.doi.org/10.33846/hn41104

http://heanoti.com/index.php/hn

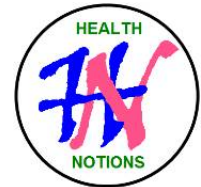

RESEARCH ARTICLE

URL of this article: http://heanoti.com/index.php/hn/article/view/hn41104

\title{
The Effect of Oxytocin Massage by Using Lemongrass Oil (Cymbopogon citratus) Aromatherapy to the Increased of Breast milk Production in Breastfeeding Mothers in Mojo Health Center, Kediri, Indonesia
}

\author{
Susanti Pratamaningtyas ${ }^{(\mathrm{CA})}$, Kekoeh Hardjito², Alfi Rohmatul Hamim ${ }^{3}$ \\ ${ }^{1(\mathrm{CA})}$ Applied Bachelor of Midwifery, Poltekkes Kemenkes Malang, Indonesia; susantipratamaningtyas@yahoo.com \\ (Corresponding Author) \\ ${ }^{2}$ Applied Bachelor of Midwifery, Poltekkes Kemenkes Malang, Indonesia; koekoehhardjito@ gmail.com \\ ${ }^{3}$ Applied Bachelor of Midwifery, Poltekkes Kemenkes Malang, Indonesia; alfi.rh3@ gmail.com
}

\begin{abstract}
Breast milk is the best food for babies. In the field of midwifery there are several ways to help increase milk production. Oxytocin massage is a massage on both sides of the mothers' limbs to provide stimulation of oxytocin reflex because it gives comfort to mother. Massage using aromatherapy essential oil is useful to anticipate depression because of relaxation effect caused by smells and massage. The purpose of this research is to know the effect of oxytocin massage using lemongrass aromatherapy oil to increase milk production in breastfeeding mothers in Mojo Health Center. This research used comparative research of 2 dependent samples and comparative research of 2 independent samples designs. The sampling technique used was accidental sampling with random allocation of 16 respondents. Based on the Mc Nemar test in the group that was given the oxytocin massage using Serai Lemongrass aromatherapy oil, $\chi 2$ counting value was 4,167 . Because of $\chi 2$ counting value $>\chi 2$ table (3.841), this indicated that there was effect of the oxytocin massage using lemongrass aromatherapy oil in the production of breast milk.
\end{abstract}

Keywords: oxytocin massage; lemongrass aromatherapy oil; breast milk; breastfeeding

\section{INTRODUCTION}

Breast milk is a liquid that results from secretion of breast glands in the form of fat in a protein solution, lactose, organic salts. Breast milk is the best food for baby because contains complete nutrient in it which important and appropriate needs for baby' growth $^{(1)}$. Human breast milk has constant composition and only some of it affected by mother's diet. The fat in breast milk varies somewhat, meanwhile the carbohydrat, protein, calcium, fat and iron contents do not change $\operatorname{much}^{(2)}$. Nutrient that obtained by baby should be optimal. Giving exclusive breastfeeding means giving breast milk until 6 months without giving or changing breast milk with something else except medicine, vitamin or mineral ${ }^{(3)}$.

Giving exclusive breastfeeding until 6 months has amazing benefits for baby. Complete composition of breast milk, one of them is the antibody. Breast glands secretes colostrum in the first day until fourth day postpartum. High immunoglobulin in colostrum takes important role in treat bacteria, virus, fungi and parasite in the first life of infant ${ }^{(1)}$. According to World Health Organization (WHO) in 2000, baby who do not get breast milk have seventeen times higher risk of experiencing diarrhea and three/four times higher of upper respiratory tract infection ${ }^{(4)}$.

In World Health Assembly resolution 2001, explained that baby has the right to get exclusive breastfeeding for the first 6 months of their life, breast milk and weaning food until 2 years old or more ${ }^{(5)}$. Indonesian government in article 128 Constitution no. 362009 about health also support breastfeeding "Every babies have the right to get exclusive breastfeeding since birth until 6 months old, except for medical indications. In government regulations no. 332012 also explained that every women who gave birth should give exclusive breastfeeding to her baby, except for medical indications, there's no mother or the baby who separated from his mother ${ }^{(6)}$.

Coverage of infant's exclusive breastfeeding 0-6 months old in 2013 was 54.3\%. But it had decreased in 2014 by $52.3 \%$. The coverage of exclusive breastfeeding in 2015 increased by $55.7 \%$. These score has not met the national target which was determined in 2014 as $80 \%$. Meanwhile, coverage of exclusive breastfeeding in East Java province was $47.88 \%$ in $2013,74 \%$ in 2014 and $74.15 \%$ in 2015 . Although it almost meet the national target, 
but the score in East Java province was lower than West Nusa Tenggara province, East Nusa Tenggara province and West Sumatera province which each of them reached $86.9 \%, 77 \%, 76.1 \%$ and $75 \%$ in $2015^{(3)}$. Meanwhile, the coverage of exclusive breastfeeding in Kediri regency has increased from $73.7 \%$ in 2013 to $79.2 \%$ in 2014 , but the number decreased in 2015 by $78.2 \%{ }^{(7)}$. That coverage in Kediri also had not met the national target.

The lack of breast milk production in the first day after delivery is caused by the lack of oxytocin hormone stimulation. Physiological changes in puerperal mother can influence her psychic in turn will affect the release of oxytocin hormone $^{(8)}$. In previous study, maternal psychology and breastfeeding physiology were proven influenced several neuroendocrine mechanisms, including oxytocin ${ }^{(9)}$. Let down reflex will be delayed and disturbed if mother breastfeeding in stress conditions like anxious, worry that she can't breastfeeding her baby ${ }^{(4)}$. A study about "Massage Increase Oxytocin and Reduces Adrenocortiocotropin Hormone in Humans" showed that oxytocin hormone increased by $9 \%$ in respondents who had been given massage and decreased by $18 \%$ in respondents who were not given a massage. Adrenaline hormone decreased by $20 \%$ in respondents who had been given massage and increased by $30 \%$ in respondents who were not given the massage ${ }^{(10)}$.

There are ways to overcome breastfeeding problem. One of them is oxytocin massage. The success in giving this massage also supported by giving aromatherapy. Aromatherapy is a way of treating the body or healing disease by using essential oils that emit odors or fragrance ${ }^{(11)}$. The use of aroma therapy is not only by inhalation but also by skin massage or drink. Aroma therapy can be alternative care for infection, stress, reduce pain, improve mood, relaxation and reduce anxiety ${ }^{(12)}$. When the aroma inhaled, the compounds will stimulate brain olfactory system in limbic system. One of the biggest role of limbic system is for regulate emotion ${ }^{(11)}$. Massage by aroma therapy essential oil is beneficial to overcome depression because the relaxation effect which produced by the aroma and the massage ${ }^{(12)}$.

A study by Vidayanti (2015) about the effect of back massage by using lavender essential oil to breast milk production post caesarean section in Panembahan Senopati hospital Bantul showed that breast milk production after given the therapy was $68.8 \%$ smooth and in the control group was just $31.2 \%{ }^{(13)}$. There are some galactogogae kind of plants which can help increase milk production, one of them is Cymbopogon citratus or we called lemongrass. This essential oil has neurobehavioral and sedative effect that can relieve pain and anxiety. Lemongrass oil also can relieve muscle cramps and spasm $^{(14)}$.

From the preliminary studies in Public Health Office of Kediri Region 2016, the region with the highest rate of labor was Mojo Health Center which was $95.7 \%$ and $55 \%$ for the exclusive breastfeeding. But this number was lower than national target ${ }^{(7)}$. There were 5 from 10 postpartum mothers who breastfed their babies and complained about the small production of the milk and gave formula milk to their babies.

Based on the preliminary study result interested in studying about the effect of oxytocin massage by using lemongrass oil (Cymbopogon citratus) aromatherapy to the increased of breast milk production in breastfeeding mothers in Mojo Health Center Kediri Region.

\section{METHODS}

This study was quantitative study that used comparative studies of two paired samples and comparative two free samples design. Taken 16 samples from all mothers who breastfeeding in the region of Mojo Health Center Kediri Region with accidental sampling which divided into two group, 8 samples for control group would be given usual oxytocin massage and the rest for experimental group would be given oxytocin massage by using lemongrass oil aromatherapy. Before gave the treatment, respondents would be observed first. The treatment would be given one time in a day for 3 days every afternoon. After the treatments were done, then the second observation would be done.

Researcher observed respondents behavior in breastfeeding by using observation and interview sheets by quality improvement breastfeeding team 2015. Points for mothers include tense feeling in the breast before feeding, breast feels empty after feeding, having nipple fissure, breast pain/congestion, express breastfeeding, breastfeeding latch. For the baby include urinate at least 6-8 times a day, the color is pale clear and no strong odor, defecate at least 2 times a day (at least the size of thumb / index finger phalange), yellowish color, mushy or in the form of seeds, feeds at least 8 times a day (5-40 minutes each time), baby calms down and releases the attachment of the breast. It was said to be smooth breast milk production if more than 4 points were both in mother and baby or just one of them. On the contrary, it was said to be not smooth if less than 4 points were both in mother and baby or just one of them.

The inclusion criteria were mothers in their third - fifth days after birth, mothers who breastfed the babies on demand, mothers who gave birth after more than 37 weeks, the babies who have good sucking reflects, mothers who were not using contraception with estrogen hormone, mothers who willing to be respondents. The exclusion criteria were mothers who consumed medicine for smoothing breast milk production, there was open wound or infection in mother's back, allergy or doesn't like the smell of lemongrass oil aromatherapy.

For analyzed the data about the effect of oxytocin massage by using lemongrass oil (Cymbopogon Citratus) to the increase of breast milk production in breastfeeding mothers, statistic test Mac Nemar was used to test hypothesis of comparative two paired sample. If the data was nominal. Meanwhile, to analyzed the difference of 
breast milk production with oxytocin massage by using lemongrass oil aromatherapy and usual oxytocin massage, statistic test Fisher Exact was used to test the hypothesis of comparative 2 sample independent if the data was nominal. This study had obtained ethical clearance with number Reg. No. : 595 / KEPK - POLKESMA / 2017.

\section{RESULTS}

Table 1. The effect of usual oxytocin massage to the increase of breast milk production

\begin{tabular}{cccccccc}
\hline \multirow{2}{*}{$\begin{array}{c}\text { Breast milk } \\
\text { production }\end{array}$} & \multicolumn{4}{c}{ Given therapy } & Total & p-value & $\begin{array}{c}\chi_{\text {count }}^{2} \\
\text { value }\end{array}$ \\
\cline { 2 - 5 } & $\mathrm{n}$ & $\%$ & $\mathrm{n}$ & $\%$ & & \\
\hline Smooth & 2 & 25 & 8 & 100 & 8 & & \\
\hline Not smooth & 6 & 75 & 0 & 0 & 8 & 0.05 & 4.167 \\
\hline Total & 8 & 100 & 8 & 100 & 16 & & \\
\hline
\end{tabular}

Table 1 showed the difference of breast milk production before and after given the treatment, the result was all of respondents $(100 \%)$ had smooth breast milk production after given usual oxytocin massage. Mc Nemar test was performed on this control group showed the value of $\chi_{\text {count }}^{2}=4.167$. According to Mc Nemar values tabulation, if $\mathrm{df}=$ 1 and $\alpha=0.05$, the value of $\chi_{\text {table }}^{2}=3.841$. The comparison result was $3.841<4.167$ showed that $\mathrm{H}_{0}$ was rejected. It meant there was relation of usual oxytocin massage with the increase of breast milk production in all of respondents.

Table 2. The effect of oxytocin massage by using lemongrass oil aromatherapy to the increase of breast milk production

\begin{tabular}{|c|c|c|c|c|c|c|c|}
\hline \multirow{3}{*}{$\begin{array}{c}\text { Breast milk } \\
\text { poduction }\end{array}$} & \multicolumn{4}{|c|}{ Given therapy } & \multirow{3}{*}{ Total } & \multirow{3}{*}{ p-value } & \multirow{3}{*}{$\begin{array}{l}\chi_{\text {count }}^{2} \\
\text { value }\end{array}$} \\
\hline & \multicolumn{2}{|c|}{ Pre-test } & \multicolumn{2}{|c|}{ Post-test } & & & \\
\hline & $\mathrm{n}$ & $\%$ & $\mathrm{n}$ & $\%$ & & & \\
\hline Smooth & 1 & 12.5 & 7 & 87.5 & 8 & \multirow{3}{*}{0.05} & \multirow{3}{*}{4.167} \\
\hline Not smooth & 7 & 87.5 & 1 & 12.5 & 8 & & \\
\hline Total & 8 & 100 & 8 & 100 & 16 & & \\
\hline
\end{tabular}

Table 2 showed the difference of breast milk production before and after given the treatment, the result was almost all of respondents $(87.5 \%)$ had smooth breast milk production after given oxytocin massage by using lemongrass oil aromatherapy and some of them $(12.5 \%)$ didn't have any changes. Mc Nemar test was performed on this treatment group showed the value of $\chi_{\text {count }}^{2}=4.167$. According to Mc Nemar values tabulation, if $\mathrm{df}=1$ and $\alpha=0.05$, the value of $\chi_{\text {table }}^{2}=3.841$. The comparison result was $3.841<4.167$ showed that $\mathrm{H}_{0}$ was rejected. It meant there was relation of oxytocin massage by using lemongrass pol aromatherapy with the increase of breast milk production.

Table 3. The difference characteristic of breast milk production after given oxytocin massage by using lemongrass oil aromatherapy and usual oxytocin massage

\begin{tabular}{|c|c|c|c|c|c|c|c|}
\hline \multirow{3}{*}{ Treatment } & \multicolumn{4}{|c|}{$\begin{array}{c}\text { Characteristic of } \\
\text { breast milk production }\end{array}$} & \multirow{3}{*}{ Total } & \multirow{3}{*}{ p-value } & \multirow{3}{*}{$\rho$} \\
\hline & \multicolumn{2}{|c|}{ Pre-test } & \multicolumn{2}{|c|}{ Post-test } & & & \\
\hline & $\mathrm{n}$ & $\%$ & $\mathrm{n}$ & $\%$ & & & \\
\hline $\begin{array}{l}\text { Oxytocin massage by using } \\
\text { lemongrass oil aromatherapy }\end{array}$ & 7 & 87.5 & 1 & 12.5 & 8 & \multirow{3}{*}{0.05} & \multirow{3}{*}{0.5} \\
\hline Usual oxytocin massage & 8 & 100 & 0 & 0 & 8 & & \\
\hline Total & 15 & 93.75 & 4 & 6.25 & 16 & & \\
\hline
\end{tabular}

Table 3 showed the difference characteristic of breast milk production after given oxytocin massage by using lemongrass oil aromatherapy and usual oxytocin massage. Fisher's Exact test was performed for this analysis. Based on the result, $\rho$ value $=0.5$ and compared to $\alpha$ value $=0.05$. The comparison result was $\rho$ value $>$ $\alpha$ value $(0.5>0.05)$, it meant there was no difference of oxytocin massage by using lemongrass oil aromatherapy treatment and usual oxytocin massage treatment to the increase of breast milk production.

\section{DISCUSSION}

\section{Breast Milk Production Before and After Given Usual Oxytocin Massage}

Based on Table 1, respondents' breast milk production before given usual oxytocin massage was 8 of the, and there were 6 respondents with not-smooth milk production. The most caused by breast didn't feel tense before breastfeeding, not milking because the breast were not full, wrong nipple attachment, and breastfeeding lower than 8 times in a day. After given usual oxytocin massage, all of the respondents had smooth breast milk production. Cross tabulation was done using chi square test and got the result there was relation of usual oxytocin massage with the increase of breast milk production. 
The most common cause of low breast milk supply are mothers milk insufficiency, age, parity, education, religion, family structure, socioeconomic status that can lead to stress condition to mother and inhibits the production of oxytocin which will indirectly make prolactin low and reduced milk production ${ }^{(15)}$. Another study told that insufficient milk supply may be a secondary effect from nipple pain which caused by incorrect positioning and attachment when breastfeed the baby ${ }^{(16)}$.

Oxytocin massage is massage that applied in the both side of spine which can stimulate oxytocin reflex because it's comfortable for mother ${ }^{(17)}$. Precisely, this massage carried out along vertebrae to the fifth-sixth costae bone and the effect can be seen after 6-12 hours. The action can be provides a relaxed sensations in mother and expedite nerve's flow and milk ducts in both breasts ${ }^{(18)}$.

A study by Sulaeman showed that there was significant difference of breast milk production in postpartum mothers that given oxytocin massage and who were not given oxytocin massage ${ }^{(19)}$. It also could be happened because of the wrong technique in milking breast milk. The right attachment position also help in breastfeeding because the most part of areola was covered by baby's mouth, so that the baby can sucking slowly and do not hurt the nipples ${ }^{(20)}$.

In another study, after given usual oxytocin massage, from 6 respondents, there was 3 respondents with smooth breast milk production (60\%). This result is in accordance with previous study by Mardiyaningsih (2010). By oxytocin massage, mothers would feel more relax after labor and it could stimulate oxytocin hormone to produce more breast milk ${ }^{(21)}$.

The result of this study is supported by study from 2014 which showed that with oxytocin massage, breast milk production will be more smooth, and it give comfort to mothers. Physiologically, it can stimulate oxytocin reflex or let down reflex to secrete oxytocin hormone to blood. This oxytocin causes myioepithelial cells around the alveoli to contract and load milk flowing from the alveoli to the ductuli into the sinuses and nipples then sucked by the baby ${ }^{(22)}$.

\section{Breast Milk Production Before and After Given Oxytocin Massage by Using Lemongrass Oil Aromatherapy}

Based on the result, in Table 2 showed that there was 7 respondents who didn't have smooth breast milk production before given the treatment. According to primary data, non-smooth production of breast milk mostly caused by some factors from mother that were incorrect attachment between baby's mouth and mother's nipple when breastfeeding, breast didn't feel tense before breastfeeding and didn't feel empty after breastfeeding. Meanwhile, from baby's factors was breastfeeding's frequency was lower than 8 times in a day. After given oxytocin massage using lemongrass oil aromatherapy, the breast milk production became smooth for $87.5 \%$ of respondents.

It can be caused by some factors like maternal psychology, resting patterns and sucking reflects on baby. Tense breast is the sign of breast milk production indicator where breasts are tense caused by prolactin works on breast ducts to produce milk. Breastfeeding frequency is very influential on breast milk production. The less baby sucks the nipples, the less milk produces. Baby's suck can stimulate tip of sensory nerve around beast and then stimulates the front pituitary gland to produce prolactin ${ }^{(20)}$.

Based on the result, after given treatment oxytocin massage by used lemongrass oil aromatherapy, 1 respondent with smooth breast milk production didn't have any changes. In 7 respondents with not-smooth breast milk production, 6 respondents had changes to have smooth milk production. The most changes occurred after the treatment were right nipple attachment, and respondents who felt the breast tense before breastfeeding also increased.

Oxytocin massage is back massage which belongs to one of intervention to increase breast milk production's smoothness. Oxytocin massage is done by massaging the backs along the spine to stimulate the letdown reflex through somatic sensory stimulation system ${ }^{(13)}$. Meanwhile, lemongrass oil aromatherapy has a distinctive aroma of lemongrass produced by geranial and neral compounds. Geranial compound has stronger lemon aroma, and neral has less strong aroma but sweeter. Citral in lemongrass oil stimulates the activation of central nervous system. Besides that, lemongrass can be used to reduce pain ${ }^{(23)}$. Lemongrass is one of herbs which listed as galactagogues. Galactagogue is material or action that can stimulate milk production on mothers ${ }^{(24)}$.

On bivariate analysis, it was concluded that there was the difference in breast milk production before and after given oxytocin massage by used lemongrass oil aromatherapy.

In earlier study from Indonesia in 2018, 10 samples were taken with purposive sampling and the result was oxytocin massage which done by using lemongrass extract aromatherapy influenced the production of breast milk $^{(25)}$.

Another research was using herbal tea on breast milk production and prolactin secretion by mothers of preterm babies. This herbal tea that used contain $1.0 \%$ of stinging nettle and mixture of other herbs that include in essential galactagogue which were melissa, caraway, anise, fennel, goat's rue and lemongrass. The treatment group results had less milk supply in first day than placebo group and control group but the flow lasted until the 
$7^{\text {th }}$ day, unlike the placebo group and control group which down. Not just the milk supply, but it also happened in their serum prolactin levels (26).

After given oxytocin massage by used lemongrass oil aromatherapy and the usual one, almost all of respondents had smooth breast milk production. Based on statistical test, there was no difference in the increased of breast milk production after oxytocin massage with lemongrass oil aromatherapy or the usual massage.

\section{The Difference Characteristic of Breast milk Production After Given Oxytocin Massage by Using Lemongrass Oil Aromatherapy and Usual Oxytocin Massage}

There was no difference of oxytocin massage by using lemongrass oil aromatherapy treatment and usual oxytocin massage treatment to the increase of breast milk production. This study is not in accordance with the previous study, about the effect of oxytocin massage by using another aromatherapy which is lavender essential oil to breast milk production post caesarean section in Panembahan Senopati hospital Bantul which told that there was an effect of oxytocin massage by using aromatherapy oil ${ }^{(13)}$. This mismatch of this study's result is likely due to maternal psychological factors, nutrition by the mother and baby suction factors that can also affect breast milk production.

\section{CONCLUSION}

Lemongrass is known to be galactagogue. Aromatherapy can help mothers relax. This feeling of relax and comfort will help mothers through the lactation process. Giving lemongrass aromatherapy is another alternative that can be done in conjunction with oxytocin massage therapy to achieve maximum result without any adverse effects.

\section{REFERENCES}

1. Dewi VNL, Sunarsih T. Asuhan Kebidanan Ibu Nifas. Suslia A, editor. Jakarta: Salemba Medika; 2014. 198 p.

2. Segura SA, Ansótegui JA, Díaz-Gómez NM. The Importance of Maternal Nutrition during Breastfeeding : Do breastfeeding mothers need nutritional supplements? An pediatría [Internet]. 2016;84(6):347.e1-347.e7. Available from: https://www.analesdepediatria.org/en-the-importance-maternal-nutrition-during-articuloS2341287916300643

3. Kemenkes RI. Profil Kesehatan Indonesia Tahun 2016 [Internet]. Jakarta; 2016. Available from: https://pusdatin.kemkes.go.id/resources/download/pusdatin/profil-kesehatan-indonesia/Profil-KesehatanIndonesia-2016.pdf

4. Astutik RY. Payudara dan Laktasi. Jakarta: Salemba Medika; 2014. 158 p.

5. IDAI. Air Susu Ibu dan Hak Bayi [Internet]. 2013 [cited 2017 Jan 1]. Available from: https://www.idai.or.id/artikel/klinik/asi/air-susu-ibu-dan-hak-bayi

6. Kemenkes RI. Profil Kesehatan Indonesia Tahun 2015 [Internet]. 2015 [cited 2017 Jan 1]. p. 403. Available from: https://www.kemkes.go.id/resources/download/pusdatin/profil-kesehatan-indonesia/profil-kesehatanIndonesia-2015.pdf

7. Dinkes Kabupaten Kediri. Profil Kesehatan Kabupaten Kediri [Internet]. Kabupaten Kediri; 2016. Available from:

https://www.kemkes.go.id/resources/download/profil/PROFIL_KAB_KOTA_2016/3506_Jatim_Kab_Kedi ri_2016.pdf

8. Marmi. Asuhan Kebidanan pada Masa Nifas "Puerperium Care.” Yogyakarta: Pustaka Belajar; 2015. 237 p.

9. Meltzer-Brody AMSKGS. Association between maternal moood and oxytocin response to breastfeeding. J Woman's Heal [Internet]. 2013;22(4):352-61. Available from: https://pubmed.ncbi.nlm.nih.gov/23586800/\#: :text=Among the 39 women who,p\%3C0.05) during feeding.

10. Morhenn V, Beavin LE, Zak PJ. Massage Increases Oxytocin and Reduces Adrenocorticotropin Hormone in Humans. Altern Ther [Internet]. 2012;18(6):11-8. Available from: https://pubmed.ncbi.nlm.nih.gov/23251939/

11. Muchtaridi, W. MM. Aroma Terapi : Tinjauan Aspek Kimia Medisinal. Yogyakarta: Graha Ilmu; 2015. 115 p.

12. Erlich S. Aromatherapy [Internet]. University of Maryland Medical Center. 2011 [cited 2016 Dec 23]. Available from: http://umm.edu/health/medical/altmed/treatment/aromatherapy

13. Vidayanti V, Hartati MS. Pengaruh Pijat Punggung Menggunakan Minyak Esensial Lavender terhadap Produksi ASI Pasca Bedah Sesar di RSUD Panembahan Senopati Bantul. Publ Univ Gadjah Mada [Internet]. 2014; Available from: http://etd.repository.ugm.ac.id/penelitian/detail/71588

14. Shah G, Shri R, Panchal V, Sharma N, Singh B, Mann AS. Scientific basis for the therapetic use of Cymbopogon citratus, stapf (Lemon grass). J if Adv Pharm Technol Res [Internet]. 2011;2(1):3-8. Available from: https://www.ncbi.nlm.nih.gov/pmc/articles/PMC3217679/\#: :text=Cymbopogon citratus\%2C Stapf (Lemon grass) is a widely used,countries\%2C especially in Southeast Asia.\&text=Studies indicate that Cymbopogon citratus, antifungal and anti-inflammatory properties. 
15. Sultana A, Rahman KU, MS MS. Clinical Update and Treatment of Lactation Insufficiency. Med J Islam World Acad Sci [Internet]. 2013;21(1):19-28. Available from: https://jag.journalagent.com/ias/pdfs/IAS_21_1_19_28.pdf

16. Kent JC, Ashton E, Hardwick CM, Rowan MK, Chia ES, Fairclough KA, et al. Nipple Pain in Breastfeeding Mothers : Incidence, Causes and Treatments. Int J Environ Res Public Health [Internet]. 2015;12(10):1224763. Available from: https://www.ncbi.nlm.nih.gov/pmc/articles/PMC4626966/pdf/ijerph-12-12247.pdf

17. Purba FBM. Buku Pintar ASI dan Menyusui. 3rd ed. Jakarta: Noura Books; 2014. 288 p.

18. Kurniyati, Bakara DM, Susanti E. The Effect of Oxytocin Massage Method Using Lavender Essential Oils on The Smooth Production of Breast Milk at Mother Postpartum in Rejang Labong Regency. Atl Press Adv Health Sci Res [Internet]. 2019;14:91-4. Available from: https://www.atlantis-press.com/proceedings/icihc$18 / 55916774$

19. Sulaeman ES, Ynita FA, Yuneta HAEN, Khotijah, Ada YR, Wijayant R, et al. The Effect of Oxytocin Massageon The Postpartum Mother on Breastmilk Production in Surakarta Indonesia. In: International Conference on Health and Well-Being [Internet]. Surakarta: Universitas Muhammadiyah Surakarta; 2016. p. 279-88. Available from: https://publikasiilmiah.ums.ac.id/handle/11617/7413

20. Nugroho T. Asi dan Tumor Payudara. Yogyakarta: Nuha Medika; 2011. 140 p.

21. Mardiyaningsih E, Setyowati, Sabri L. Efektifitas Kombinasi Teknik Marmet dan Pijat Oksitosin terhadap Produksi ASI Ibu Post Seksio di Rumah Sakit Wilayah Jawa Tengah. J Keperawatan Soedirman [Internet]. 2011;06(1). Available from: http://jks.fikes.unsoed.ac.id/index.php/jks/article/view/321

22. Warsiti LW. Pengaruh Pijat Oksitosin Terhadap Produksi ASI pada Ibu Postpartum di Puskesmas Mergangsan Yogyakarta Tahun 2014. Publ Univ 'Aisyiyah Yogyakarta [Internet]. 2014; Available from: http://digilib.unisayogya.ac.id/1076/

23. Evizal R. Tanaman Rempah dan Fitomarmaka [Internet]. Lembaga Penelitian Universitas Lampung. [cited 2017 Jan 1]. Available from: http://vebuka.com/print.php?documentId=1410011055495758eae60227b6202b1f661099229006\&count $=214$

24. Lawrence R, Lawrence R. Medications, Herbal Preparations, and Natural Products in Breast Milk. In: Breastfeeding [Internet]. 8th ed. Elsevier Inc; 2015. p. 364-405. Available from: https://www.elsevier.com/books/breastfeeding/lawrence/978-0-323-35776-0

25. Yanti S. Pengaruh Pijat Oksitosin dengan Aromaterapi Ekstrak Serei Wangi terhadap Produksi ASI pada Ibu Nifas di Wilayah Kerja Puskesmas Kolok Kota Sawahlunto Tahun 2018. Publ Univ Fort Kock [Internet]. 2018; Available from: https://repository.fdk.ac.id/journal/detail/4059/pengaruh-pijat-oksitosin-denganaromaterapi-ekstrak-serei-wangi-terhadap-produksi-asi-pada-ibu-nifas-di-wilayah-kerja-puskesmas-kolokkota-sawahlunto-tahun-2018

26. Özalkaya E, Aslandoğdu Z, Özkoral A, Topcuoğl S, Karatekin G. No Title. Niger J Clin Pract [Internet]. 2018;21(1):38-42. Available from: https://www.njcponline.com/article.asp?issn=11193077 ; year $=2018$; volume $=21 ;$ issue $=1$; spage $=38$; epage $=42 ;$ aulast $=\%$ D6zalkaya 